\title{
Pretreatment of Gymnema sylvestre revealed the protection against acetic acid-induced ulcerative colitis in rats
}

\author{
Abdulaziz M Aleisa', Salim S Al-Rejaie ${ }^{1 *}$, Hatem M Abuohashish ${ }^{1,2}$, Mohammed S Ola ${ }^{3}$, Mihir Y Parmar ${ }^{1}$ \\ and Mohammed M Ahmed'
}

\begin{abstract}
Background: Overproduction of free radicals and decreased antioxidant capacity are well-known risk factors for inflammatory bowel diseases. Gymnema sylvestre (GS) leaves extract is distinguished for its anti-diabetic, antioxidant and anti-inflammatory properties. Present study is designed to evaluate the preventative activities of GS against acetic acid (AA)-induced ulcerative colitis in Wistar rats.

Methods: Experimentally ulcerative colitis (UC) was induced by AA in animals pretreated with three different doses of GS leaves extract (50, 100, $200 \mathrm{mg} / \mathrm{kg} /$ day) and a single dose of mesalazine (MES, $300 \mathrm{mg} / \mathrm{kg} /$ day) for seven days. Twenty four hours later, animals were sacrificed and the colonic tissues were collected. Colonic mucus content was determined using Alcian blue dye binding technique. Levels of thiobarbituric acid reactive substances (TBARS), total glutathione sulfhydryl group (T-GSH) and non-protein sulfhydryl group (NPSH) as well as the activity of the antioxidant enzymes superoxide dismutase (SOD) and catalase (CAT) were estimated in colon tissues. Colonic nucleic acids (DNA and RNA) and total protein (TP) concentrations were also determined. Levels of pro-inflammatory cytokines including interleukin-1 beta (IL-1 $\beta$ ), tumor necrosis factor-alpha (TNF-a) and interleukin-6 (IL-6) as well as prostaglandin $\mathrm{E}_{2}\left(\mathrm{PGE}_{2}\right)$ and nitric oxide $(\mathrm{NO})$ were estimated in colonic tissues. The histopathological changes of the colonic tissues were also observed.
\end{abstract}

Results: In AA administered group TBARS levels were increased, while colonic mucus content, T-GSH and NP-SH, SOD and CAT were reduced in colon. Pretreatment with GS inhibited TBARS elevation as well as mucus content, T-GSH and NP-SH reduction. Enzymatic activities of SOD and CAT were brought back to their normal levels in GS pretreated group. A significant reduction in DNA, RNA and TP levels was seen following AA administration and this inhibition was significantly eliminated by GS treatment. GS pretreatment also inhibited AA-induced elevation of pro-inflammatory cytokines, $\mathrm{PGE}_{2}$ and NO levels in colon. The apparent UC protection was further confirmed by the histopathological screening.

Conclusion: The GS leaves extract showed significant amelioration of experimentally induced colitis, which may be attributed to its anti-inflammatory and antioxidant property.

Keywords: Gymnema sylvestre, Inflammatory bowel diseases, Oxidative stress, Ulcerative colitis

\footnotetext{
* Correspondence: rejaie@hotmail.com

'Department of Pharmacology and Toxicology, College of Pharmacy, King

Saud University, P.O. Box 2457, Riyadh 11451, Saudi Arabia

Full list of author information is available at the end of the article
} 


\section{Background}

Ulcerative colitis and Crohn's disease (CD) are mutually known as inflammatory bowel disease (IBD). Epidemiologically, IBD are heterogenic distributed disorder around the world [1]. In the United States and Western communities the incidence of UC is 7\%, with a peak incidence between ages 20 and 25 years. Several etiological factors were suggested to be implicated in the pathogenesis of UC including genetic, immunological, and environmental factors. However, the exact pathophysiology of the disease is still unclear [2].

Inflammatory changes associated with UC are limited to the mucosa and typically affects the rectum but often extends to involve the whole colon [3,4]. Both excessive inflammation and oxidative stress play a pivotal role in the pathogenesis of UC $[5,6]$. The pathophysiology of UC as an inflammatory disease mainly characterized by migration of neutrophils, basophils and other leukocytes to the mucosa membranes and the superficial ulcers [7]. This process leads to release of inflammatory mediators such as cytokines and arachidonic acid metabolites, as well as free radicals resulting in oxidative damage to the colonic tissue $[8,9]$. Studies demonstrated that oxidative injury resulting from free radicals overproduction such as reactive oxygen species (ROS) and reactive nitrogen species (RNS) in patients with colitis can lead to adverse effects such as lipid peroxidation (LPO) of the cellular membrane and attack on tissue proteins and nucleic acids [10]. Generation of ROS and the subsequent LPO reduces cellular antioxidant capacity, which leads to prominent colonic inflammation. Management of UC using therapies with limited toxicity is a severe challenge.

The commonly used medical treatments for UC include 5-aminosalicylic acid, corticosteroids, azathioprine, 6mercaptopurine, methotrexate, cyclosporine, antibiotics (e.g., metronidazole, ciprofloxacin, and vancomycin), and the TNF antagonist, infliximab [11]. These medications lack specificity and are linked with numerous side effects. Therefore, there is an urgent need to develop an effective and safe treatments and therapeutic approaches to treat such a disease in order to improve quality of life and psychosocial functioning of patients.

Several medicinal plants are characterized by their antioxidant and anti-inflammatory properties. In the study we focused on utilizing GS R. Br. a well-known medicinal plant from Asclepiadaceae family which is widely distributed in Southern India, tropical Africa and Australia, where it has been used traditionally as a folklore medicine [12]. Previous studies showed medical benefits of GS in improving urination, stomach stimulation, and diabetes [13-15]. GS leaves contains a group of triterpenoids and saponins known as gymnemic acids [12,16], alkaloids, acidic glycosides and anthroquinones and their derivatives [17]. These active constituents were found to promote ulcer healing by forming protective mucus barrier [18]. As shown in earlier studies, overproduction of ROS and inflammation plays an important role in the pathogenesis of UC, leading to oxidative damage in colonic tissues $[5,19,20]$. With respect to the high antioxidant capacity and anti-inflammatory activity, GS would be expected to reduce injury and/or improve tissue healing following injury from ulcerative colitis. In the present study, the preventative properties of GS leaves extract was evaluated by measuring potential pro oxidative and inflammatory markers known to damage the tissue in experimental model of UC by AA in Wistar rats.

\section{Methods \\ Animals}

The present study was conducted using 12 weeks old male Wister albino rats weighting 250-280 g. Animals were supplied by the Experimental Animal Care Center, College of Pharmacy, King Saud University, Riyadh, Saudi Arabia. Controlled environmental conditions $\left(25^{\circ} \mathrm{C}\right.$ and a $12 \mathrm{~h}$ light/dark cycle) were provided to the animals, which had a free access to Purina rat chow (Manufactured by Grain Silos and Flour Mills Organization, Riyadh, Saudi Arabia) and tap water. Animal experiments were conducted after official approval by following the guidelines of the Ethics Committee of the Experimental Animal Care Center, College of Pharmacy, King Saud University, Riyadh, Saudi Arabia.

\section{Plant extract}

GS leaves dried ethanolic extract filled in capsules (200 $\mathrm{mg}$ in each) with the brand name "Diaglu" manufactured by MEPACO, Egypt and the recommended therapeutic dose was one capsule twice a day as dietary supplement. The extract used in present study was standardized as $25 \%$ gymneric acids as major constituents besides there are anthroquinones and their derivatives present in the extract. The dried powder was suspended in $0.25 \%$ carboxymethyl cellulose $(\mathrm{CMC})$ solution and administered orally (gavage) in the doses of 50, 100 and $200 \mathrm{mg} / \mathrm{kg}$ body weight to fasted Wistar rats. The three doses of the extract have taken to find the dose dependent effect.

\section{Phytochemical analysis}

GS dried ethanol leaves extract was screened for its phytochemical constituents using Agilent 6410 Triple Quadrupole Mass Spectrometer (Agilent Technologies, Santa Clora, CA, USA), which was equipped with an electrospray ionization interface coupled to an Agilent 1200 HPLC (Agilent Technologies, Santa Clora, CA, USA). Direct injection of the samples was allowed by a connector instead of the column. Two solvents were in the mobile phase: (A) HPLC grade water and (B) 
acetonitrile $(\mathrm{ACN})$, which were mixed in 1:1 ratio. For mass spectrometry (MS), test solutions were prepared by diluting the stock solutions with $\mathrm{ACN} / \mathrm{H}_{2} \mathrm{O}$ mixture. Using a flow rate of $0.4 \mathrm{~mL} / \mathrm{min}$ and a run time of $3 \mathrm{~min}, 10 \mu \mathrm{L}$ from each sample was injected into the LC-MS/MS. MS parameters were optimized for scan mode. The mass range of $\mathrm{m} / \mathrm{z}$ 650-850 was used to perform MS2 scans for mass signals screening of the different compounds.

\section{Chemicals}

Mesalazine was purchased from Shire pharmaceuticals Inc. USA. Thiobarbituric acid reactive substances (TBARS) assay kit was purchased from ZeptoMetrix Inc, USA. Tumor necrosis factor- $\alpha$ (TNF- $\alpha)$, interleukin-1 $\beta$ (IL-1 $\beta$ ), interleukin-6 (IL-6), prostaglandin $\mathrm{E}_{2}\left(\mathrm{PGE}_{2}\right)$ and nitric oxide (NO) kits were purchased from $R \& D$ systems Inc, USA. All other chemicals used were of analytical reagent grade.

\section{Experimental design}

Animals were randomly allocated into seven groups (six animals in each) as follows: Control (Cont), AA treated rats, GS $200 \mathrm{mg} / \mathrm{kg} /$ day, GS $50 \mathrm{mg} / \mathrm{kg} /$ day + AA, GS $100 \mathrm{mg} / \mathrm{kg} /$ day + AA, GS $200 \mathrm{mg} / \mathrm{kg} /$ day + AA and MES $300 \mathrm{mg} / \mathrm{kg} /$ day + AA. GS dried ethanol leaves extract and MES were treated to the rats for 7 consecutive days by gavage [21]. At the 7th day of treatment, UC was induced in all AA groups. $24 \mathrm{hr}$ later, animals were sacrificed under deep anesthesia [22] and 5-6 cm of the colon specimens were dissected, washed with saline solution and weighted. A small cross section of colon tissue from each group was fixed in $10 \%$ formaldehyde solution for histopathological screening. The remaining colonic tissues were kept at $-75^{\circ} \mathrm{C}$ (Ultra-low freezer, Environmental Equipment, Cincinnati, Ohio, USA) for biochemical analysis.

\section{Induction of UC in rats}

The experimental induction of UC was performed in accordance with Mousavizadeh et al. method [23]. Using a $2.7 \mathrm{~mm}$ soft pediatric catheter, animals were transrectally administered $2 \mathrm{~mL}$ of $4 \%$ AA solution (v/v; Merck, Darmstadt, Germany) under light ether anesthesia. To avoid AA leakage, rats were then holed horizontally for 2 minutes. Exactly similar procedure was performed to control animals using equal volume of normal saline instead of AA solution.

\section{Estimation of the adherent colonic mucus}

The method described by Popov et al. [24] was used to estimate the colon adherent mucus concentration. A small sections from animals colonic tissues were transferred immediately after weighing to a solution of $1 \%$
Alcian blue and $0.16 \mathrm{~mol} / \mathrm{L}$ sucrose solution $(\mathrm{pH} 5)$ for $24 \mathrm{hr}$. The sucrose solution was used to rinse the excess dye. The complexed dye with the colonic wall mucus was extracted using $0.5 \mathrm{~mol} / \mathrm{L} \mathrm{MgCl} 2$ solution. Then, the blue extract was mixed with diethyl ether in a ratio of 1:1. After centrifugation at 4000 RPM, the absorbance of the aqueous layer was measured at $580 \mathrm{~nm}$. The quantity of Alcian blue extracted in $\mu \mathrm{g} /$ grams of the wet colon was then calculated.

\section{Estimation of TBARS levels in colon}

The LPO product malondialdehyde (MDA) was estimated by using an assay kit of TBARS in colon tissue (ZeptoMetrix Inc, USA). In brief, $100 \mu \mathrm{L}$ of the colon tissue homogenate was mixed with $2.5 \mathrm{~mL}$ the kit reaction buffer then heated for $1 \mathrm{hr}$ at $95^{\circ} \mathrm{C}$. After cooling, the absorbance of the supernatant was measured at $532 \mathrm{~nm}$. The LPO products are expressed in terms of nmoles $\mathrm{MDA} / \mathrm{mg}$ protein.

\section{Estimations of T-GSH and NPSH concentrations in colon}

The procedure described by Sedlak et al. [25] was used to determine colonic concentration of T-GSH and NP$\mathrm{SH}$. For the T-GSH estimation, $0.5 \mathrm{~mL}$ of the cold $0.02 \mathrm{~mol} / \mathrm{L}$ EDTA colon tissues homogenate was added to $0.2 \mathrm{~mol} / \mathrm{L}$ Tris buffer $(\mathrm{pH} 8.2)$ and $0.1 \mathrm{~mL}$ of $0.01 \mathrm{~mol} / \mathrm{L}$ Ellman's reagent, [5,5'-dithiobis-(2-nitr-benzoic acid)] (DTNB). Then samples were centrifuged at $3000 \mathrm{rpm}$ for $15 \mathrm{~min}$. The absorbance of the clear supernatant was measured at $412 \mathrm{~nm}$ by using spectrophotometer (LKB-Pharmacia, Mark II, Ireland). For NP-SH estimation, the homogenate was mixed with $1 \mathrm{~mL}$ of $50 \%$ trichloroacetic acid (TCA). Samples were then shaken intermittently for 10-15 min and centrifuged for $15 \mathrm{~min}$ at $3000 \mathrm{rpm}$. In a ratio of 1:2 the supernatant was mixed with $0.4 \mathrm{~mol} / \mathrm{L}$ Tris buffer $(\mathrm{pH} 8.9)$ then $0.1 \mathrm{~mL}$ DTNB was added. The absorbance of the mixture was read within $5 \mathrm{~min}$ at $412 \mathrm{~nm}$.

\section{Estimation of SOD and CAT activities in colon}

The enzymatic activity of the antioxidant enzyme SOD was measured in post-mitochondrial supernatant of the colon homogenate by Kono [26] method. Superoxide anions generated hydroxylamine hydrochloride oxidation mediate nitro-bluetetrazolium reduction to a blue formazon, which was then measured at $560 \mathrm{~nm}$ under aerobic conditions. Superoxide dismutase inhibits nitrobluetetrazolium reduction. The extent of the inhibition was taken as a measure of SOD activity and expressed as units/mg protein. The CAT enzymatic activity was measured by using Aebi, [27] method. The post-mitochondrial supernatant of the colon homogenate was mixed with $50 \mathrm{mmol} / \mathrm{L}$ phosphate buffer $(\mathrm{pH} 7.0)$ and $20 \mathrm{mmol} / \mathrm{L}$ $\mathrm{H}_{2} \mathrm{O}_{2}$. The enzymatic activity CAT was determined 
following the decrease in absorbance at $240 \mathrm{~nm}$ and expressed in terms of units/mg protein.

\section{Determination of nucleic acids and total protein (TP) levels in colon}

The concentrations of nucleic acids (DNA and RNA) in colon tissues were measured in accordance with the method described by Bregman [28]. The homogenized colon tissues were suspended in $5 \mathrm{~mL}$ of $10 \%$ ice-cold trichloroacetic acid (TCA). Samples were centrifuged and the resulted pellets were extracted with $95 \%$ ethanol twice. The nucleic acids content was extracted in 5\% TCA. For DNA determination, extracts were treated with diphenylamine reagent and the resulted blue color was measured at $600 \mathrm{~nm}$. For RNA quantification, the extracts were treated with orcinol reagent and the intensity of the green color was measured at $660 \mathrm{~nm}$. Total protein in colon tissues were estimated by using Lowry [29] method following Bovine plasma albumin as a standard.

\section{Determination of inflammatory cytokines, $\mathrm{PGE}_{2}$ and NO levels in colon tissues}

Animals colon levels of pro-inflammatory cytokines including IL-1 $\beta$, IL- 6 and TNF- $\alpha$, and PGE $_{2}$ were determined by using enzyme-linked immunoabsorbent assay ELISA kits (R\&D systems Inc, USA) in accordance with Mousavizadeh et al. [23] method. The results were expressed as pg/mg tissue. The NO concentrations in colonic tissues were estimated by Griess reaction method using commercial kit (R\&D systems Inc, USA).

\section{Histopathological assessment of colitis}

Cross section of colon tissues were fixed in $10 \%$ formaldehyde solution then embedded into paraffin wax blocks and cut using a microtome. Samples were stained with haematoxylin and eosin stain (H\&E), mounted and observed microscopically by a histopathologist in blinded fashion. Histopathological slides were screened for mucosal ulceration, hyperemia, necrosis, edema, cellular infiltrate and goblet cell hyperplasia.

\section{Statistical analysis}

Experimental data were expressed as means \pm SEM Statistical analysis was carried out using one-way ANOVA followed by Newman-Keuls as post hoc test. $P$ values of $\leq 0.05$ were considered statistically significant. All statistical analysis was conducted by using Graph Pad Prism (version 5) software.

\section{Results}

\section{Phytochemical constituents of GS}

Phytochemical screening of the dried ethanol GS leaves extract revealed the presence of several gymnemic acids with different molecular weights, which are summarized in Table 1.

\section{Effect of GS on colonic weights and mucus content} In AA group, mean colonic weights were significantly $(\mathrm{P}<0.001)$ increased compared to control animals. In seven days pretreatment with different doses of GS groups showed marked reduction in mean colon weights compared to AA group (Figure 1-A). Mucus content of rats' colon in AA group was significantly $(\mathrm{P}<0.01)$ reduced compared to controls. Only in higher dose of GS and MES groups, mucus content was significantly $(P<0.05)$ increased when compared to AA group (Figure 1-B).

\section{Effect of GS on TBARS and sulfhydryl groups}

The TBARS levels were found significantly $(\mathrm{P}<0.01)$ increased in AA administered group compared to control rats. Pretreated with higher two doses of and MES rats showed inhibition in TBARS levels compared to AA group (Figure 2-A). Sulfhydryl's either in form of T-GSH or NP-SH significantly inhibited $(\mathrm{P}<0.01$ and $\mathrm{P}<0.05$, respectively) in colon tissues of AA group of animals. In pretreatments of rats with GS $100 \mathrm{mg} / \mathrm{kg}$ and $200 \mathrm{mg} / \mathrm{kg}$ ameliorated the reduced levels of T-GSH $(\mathrm{P}<0.05$ and $\mathrm{P}<0.01$, respectively) and NP-SH $(\mathrm{P}<0.05)$ compared AA group. Similarly, MES pretreatment also showed significant increase in T-GSH and NP-SH levels $(\mathrm{P}<0.001$ and $\mathrm{P}<0.05$, respectively) (Figure $2-\mathrm{B}$ and $2-\mathrm{C}$ ).

\section{Effect of GS on SOD and CAT activities in colon tissues}

Activities of the antioxidant enzymes SOD and CAT were significantly $(\mathrm{P}<0.01$ and $\mathrm{P}<0.05$, respectively) inhibited in the colons of AA administered rats compared to control animals. Pretreatment with higher doses (100, $200 \mathrm{mg} / \mathrm{kg}$ ) of GS showed marked increase in SOD activity $(\mathrm{P}<0.05$ and $\mathrm{P}<0.01$, respectively) compared to

Table 1 List of compounds found in the negative MS scan spectra of the dried ethanol GS leaves extract

\begin{tabular}{lcc}
\hline No. & Name of compound & Molecular weight \\
\hline A & Gymnemic acid I & 807 \\
B & Gymnemic acid II & 809 \\
C & Gymnemic acid III & 809 \\
D & Gymnemic acid IV & 807 \\
E & Gymnemic acid V & 807 \\
F & Gymnemic acid VII & 666 \\
G & Gymnemic acid XI & 807 \\
H & Gymnemic acid XIII & 766 \\
I & Gymnemic acid XVII & 786 \\
J & Gymnemic acid XVIII & 786 \\
K & Deacylgymnemic acid & 682 \\
L & Gymnemasin B & 828 \\
\hline
\end{tabular}




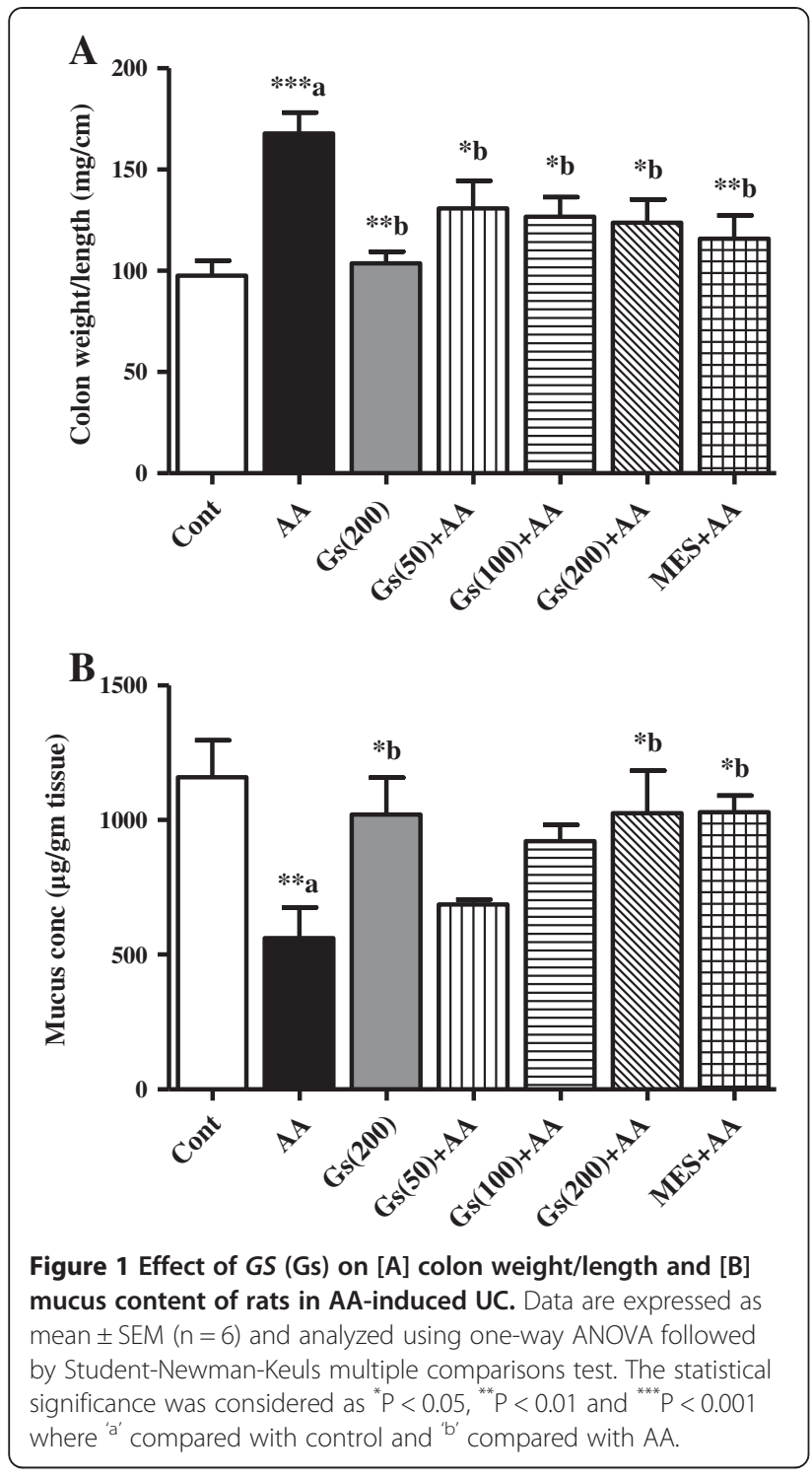

AA group (Figure 3-A). Although, only the higher dose $(200 \mathrm{mg} / \mathrm{kg})$ was able to enhance CAT activity $(\mathrm{P}<0.05)$ when compared to AA group (Figure 3-B). Pretreatment with MES produced marked increase in SOD and CAT activities $(\mathrm{P}<0.01$ and $\mathrm{P}<0.05$, respectively) compared to AA group (Figure 3-A and 3-B).

Effect of GS on nucleic acids and TP levels in colon tissues Nucleic acids (DNA and RNA) and TP levels in colon tissues were significantly $(\mathrm{P}<0.01)$ inhibited in AA administered group compared to control animals. In pretreated groups, with GS showed an increase in the DNA, RNA and TP levels when compared to AA group in a dose dependent manner and these levels were significantly increased in MES pretreated animals (Figures 4-A, 4-B and 4-C).
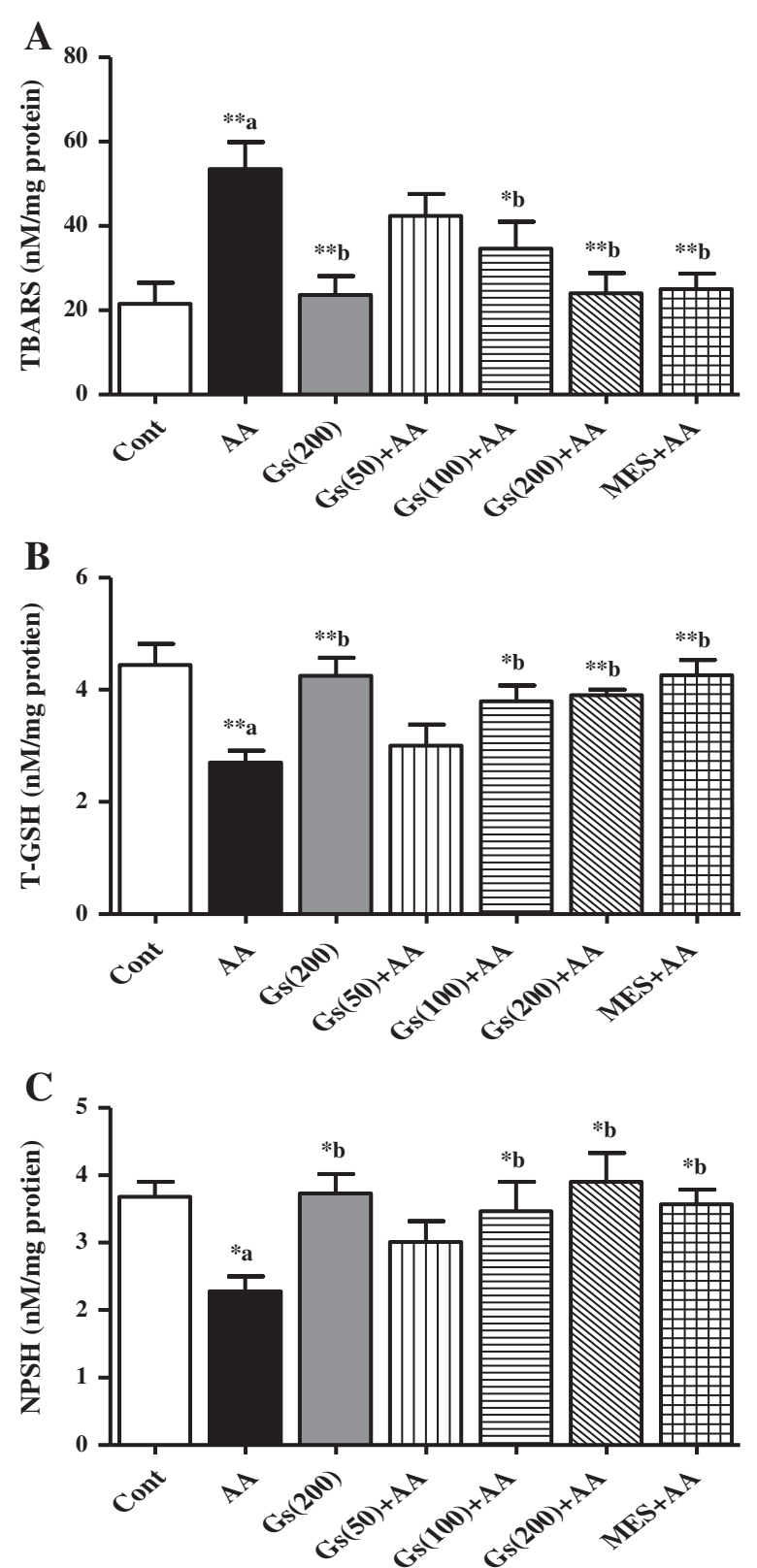

Figure 2 Effect of GS (Gs) on colonic level of [A] TBARS, [B] TGSH and [C] NPSH of rats in AA induced UC. Data are expressed as mean \pm SEM $(n=6)$ and analyzed using one-way ANOVA followed by Student-Newman-Keuls multiple comparisons test. The statistical significance was considered as ${ }^{*} \mathrm{P}<0.05,{ }^{* *} \mathrm{P}<0.01$ and ${ }^{* * *} \mathrm{P}<0.001$ where ' ${ }^{\prime}$ c compared with control and ' ${ }^{\prime}$ ' compared with $A A$.

\section{Effect of GS on pro-inflammatory cytokines in colon} tissues

Colonic levels of pro-inflammatory cytokines IL-1 $\beta$, IL-6 and TNF- $\alpha$ were significantly $(\mathrm{P}<0.05, \mathrm{P}<0.05$ and $\mathrm{P}<0.01$ respectively) increased in $\mathrm{AA}$ administered group compared to control rats. In all GS pretreated groups a significant $(P<0.05)$ lower levels of IL-1 $\beta$ was found (Figure 5A). While $100 \mathrm{mg} / \mathrm{kg}$ and $200 \mathrm{mg} / \mathrm{kg}$ GS 


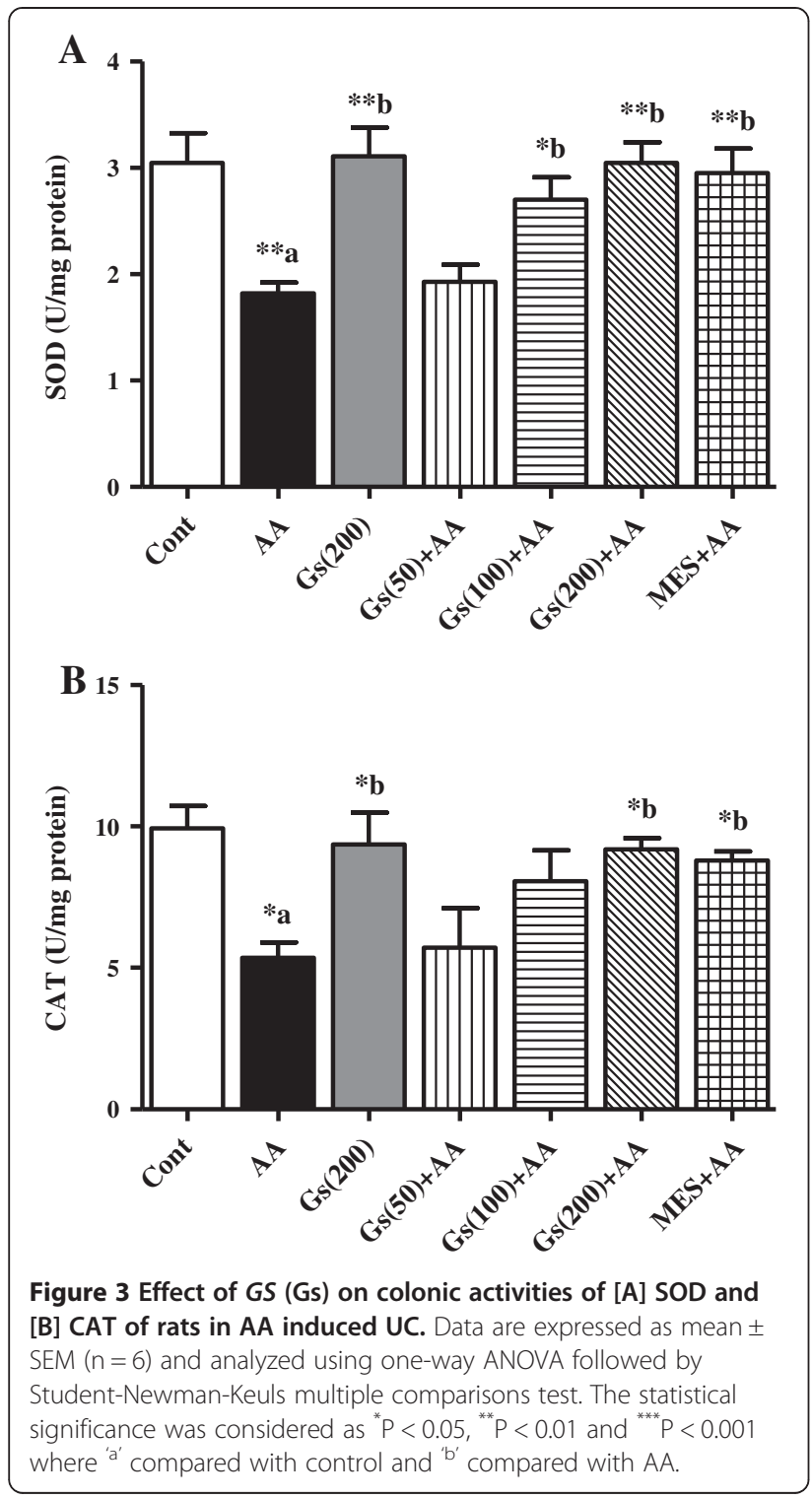

doses groups had only significant reduction in TNF- $\alpha$ $(\mathrm{P}<0.05)$ and IL-6 $(\mathrm{P}<0.05$ and $\mathrm{P}<0.01$, respectively) when compared to the animals in AA group. However, MES pretreatment showed significant decrease in all these cytokines levels when compared to AA group (Figure 5-A, 5-B and 5-C).

\section{Effect of GS on $\mathrm{PGE}_{2}$ and NO levels in colon tissues}

In addition there was a marked elevation in $\mathrm{PGE}_{2}$ and $\mathrm{NO}$ levels in colon tissues of AA administered group when compared to control ( $\mathrm{P}<0.01$ and $\mathrm{P}<0.05$, respectively). GS at $(100$ and $200 \mathrm{mg} / \mathrm{kg})$ the elevated $\mathrm{PGE}_{2}$ levels were significantly inhibited $(\mathrm{P}<0.05, \mathrm{P}<0.01$ respectively). The level of $\mathrm{PGE}_{2}$ was also inhibited in MES compared to AA groups (Figure 6-A). Similarly, NO levels in colon tissues were reduced significantly $(\mathrm{P}<0.05)$ in $G S$ pretreated rats
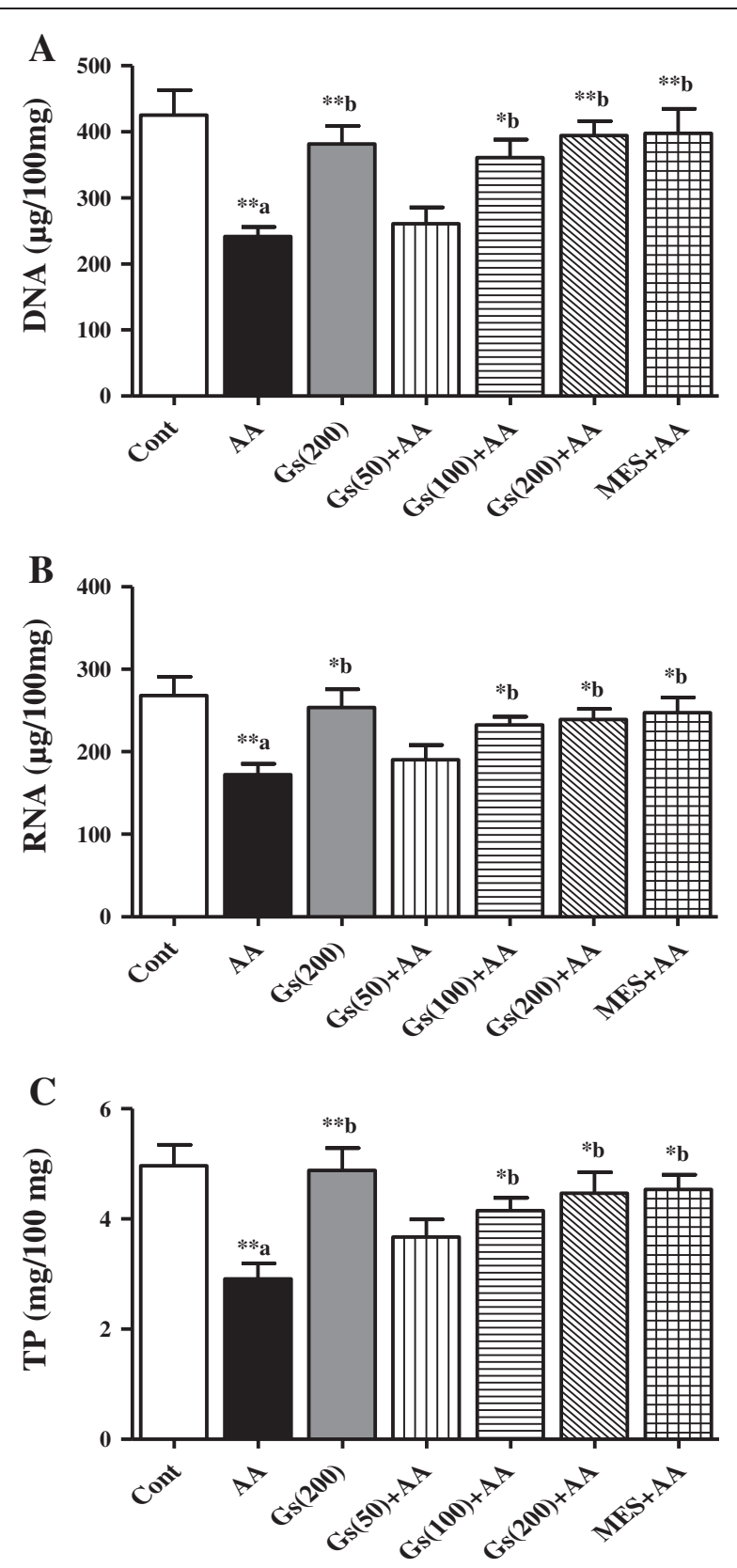

Figure 4 Effect of GS (Gs) on colonic conc of [A] DNA, [B] RNA and [C] TP of rats in AA induced UC. Data are expressed as mean \pm SEM $(n=6)$ and analyzed using one-way ANOVA followed by Student-Newman-Keuls multiple comparisons test. The statistical significance was considered as ${ }^{*} \mathrm{P}<0.05,{ }^{* *} \mathrm{P}<0.01$ and ${ }^{* * *} \mathrm{P}<0.001$ where ${ }^{\prime a}$ ' compared with control and 'b' compared with AA.

(100 and $200 \mathrm{mg} / \mathrm{kg}$ ) to AA alone. MES pretreated groups also showed significant reduction in NO levels compared to AA administered animals (Figure 6-B).

Effect of GS on histopathological changes in colon tissues As shown in Figure 7, histopathological screening of rat's colon cross sections revealed normal looking mucosal 

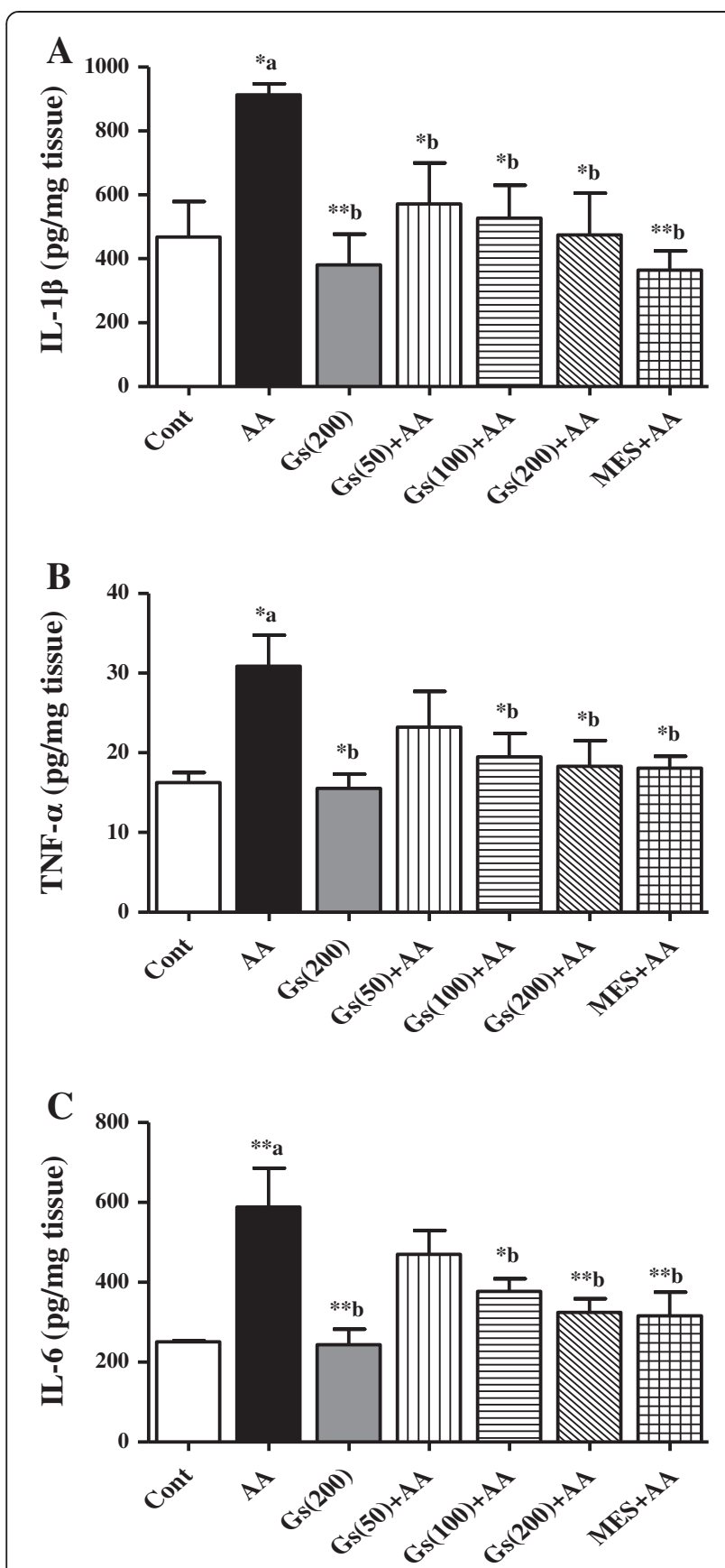

Figure 5 Effect of GS (Gs) on colonic level of [A] IL-1 $\beta$, [B] TNF$\boldsymbol{a}$ and $[\mathrm{C}] \mathrm{IL}-6$ of rats in AA induced UC. Data are expressed as mean \pm SEM $(n=6)$ and analyzed using one-way ANOVA followed by Student-Newman-Keuls multiple comparisons test. The statistical significance was considered as ${ }^{*} \mathrm{P}<0.05,{ }^{* *} \mathrm{P}<0.01$ and ${ }^{* * *} \mathrm{P}<0.001$ where 'a' compared with control and 'b' compared with AA.

epithelium with no necrosis or inflammation in the control group (Table 2 and Figure 7-A). In AA group (Figure 7-B), a diffused active UC was seen along with severe necrosis and inflammation associated with edema, goblet cell hyperplasia (Table 2 and Figure 2-B). Pretreatment with GS
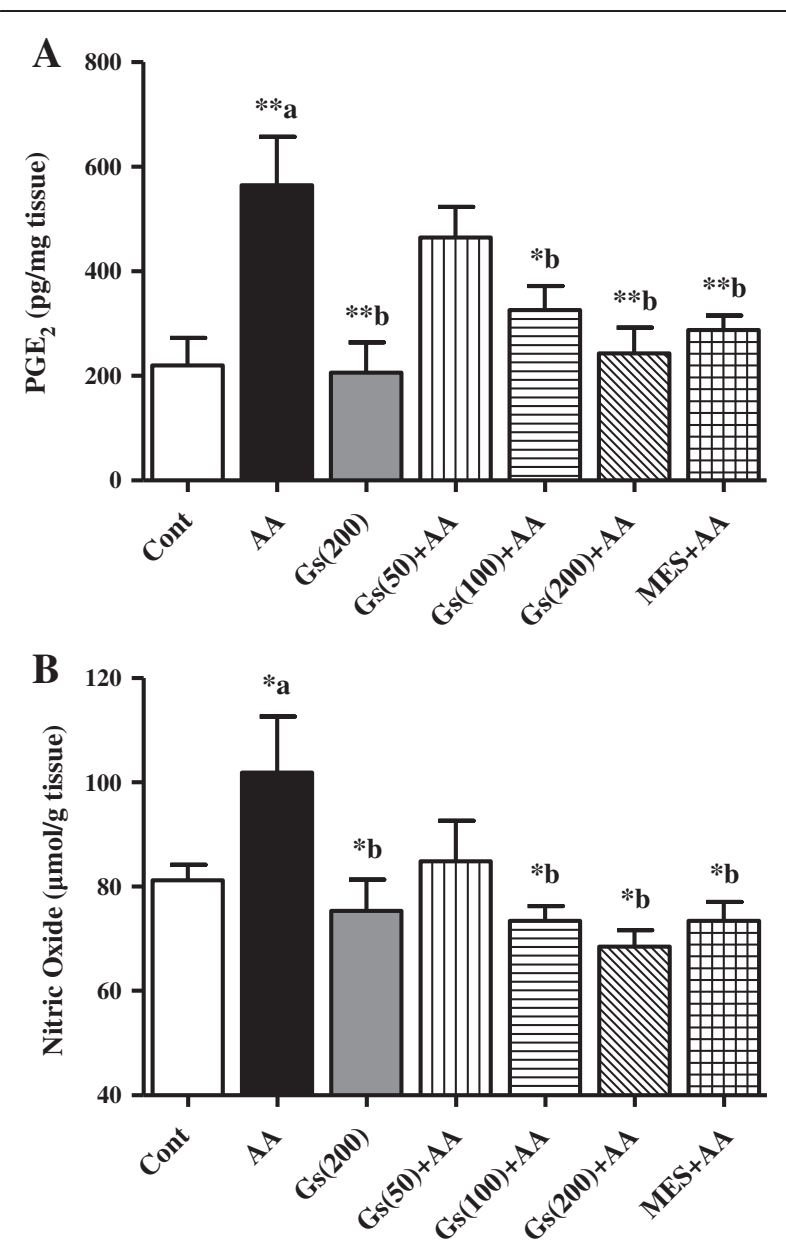

Figure 6 Effect of GS (Gs) on colonic level of [A] $\mathrm{PGE}_{2}$ and [B] NO of rats in AA induced UC. Data are expressed as mean \pm SEM $(n=6)$ and analyzed using one-way ANOVA followed by StudentNewman-Keuls multiple comparisons test. The statistical significance was considered as ${ }^{*} \mathrm{P}<0.05,{ }^{* *} \mathrm{P}<0.01$ and ${ }^{* * *} \mathrm{P}<0.001$ where $\mathrm{a}^{\prime}$ compared with control and ' ${ }^{\prime}$ ' compared with AA.

$(50 \mathrm{mg} / \mathrm{kg})$ resulted in a slight healing of epithelial cells ulceration with moderate degree of necrosis and inflammation and less goblet cells (Table 2 and Figure 7-C). However histopathological assessment of colon in GS $(100)+$ AA group revealed more healing of the mucosal epithelium with less eroded surface surrounded by fewer inflammatory edema and less necrosis (Table 2 and Figure 7-D). Pretreatment with the higher dose of GS $(200 \mathrm{mg} / \mathrm{kg})$ resulted in a total healing of the superficial eroded mucosa with little hemorrhage, edema and necrosis and fewer inflammatory cells infiltrate and goblet cells (Table 2 and Figure 7-E). Colon tissues of animals pretreated with MES $(300 \mathrm{mg} / \mathrm{kg})$ as a standard drug showed markedly healed and improved intestinal mucosa that can be compared to colon section from control animals (Table 2 and Figure 7-F). 


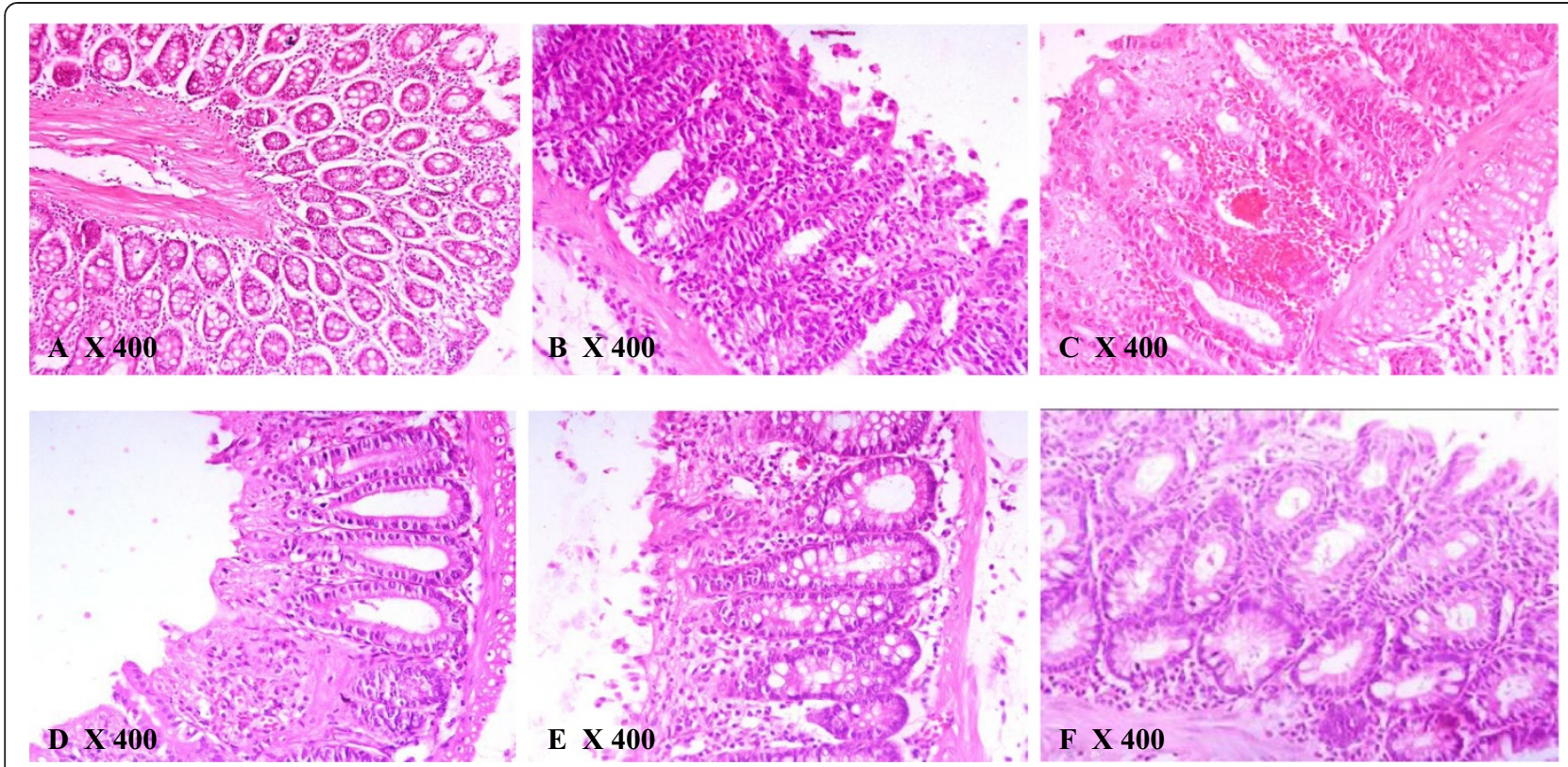

Figure 7 Histopathological sections of colons from rats stained with H\&E (400X). Colonic microscopic image of [A] Normal rat colon from Cont group with intact mucosal layer and epithelial; [B] AA treated rat colon with diffused active colitis, extensive damage including edema in submucosa and chronic inflammatory cells infiltrate with widely ulcerating mucosa, and hemorrhages; [C, D \& E] dose dependent reparative epithelial changes and ulcer healing with lymphoid follicle in colon of GS treated rats (50, 100 and 200 mg/kg , respectively); [F] attenuated cell damage with complete ulcer healing in MES treated group.

\section{Discussion}

In the present study the preventative properties of $G S$ leaves extract against experimentally induced model of IBD in Wistar rats were investigated. The histopathological assessment revealed that pretreatment with preserved the functional cytoarchitecture of the entire colonic mucosa, congestion, ulceration, erosions, necrosis and inflammation caused by AA in a dose-dependent manner. Moreover, GS leaves extract markedly protected the colonic mucosal content and prevented oxidative and inflammatory response in the colon of AA induced rats.

Experimentally induced UC by $4 \%$ AA is a wellrecognized model for IBD. The colonic changes following rectal application of AA to rodents are characterized by mucosal ulceration, hemorrhage and inflammation, which are similar to IBD in human [30]. It also causes infiltration of leukocytes to the damaged area and rupture of colonic barrier, along with an inflammatory mediator's release, including cytokines and arachidonic acid metabolites as well as release of ROS, leading to oxidative damage $[8,9]$. In the current investigation, rectal application of AA significantly increased animals colon weights, which was associated with severe tissue ulceration, necrosis, goblet cell hyperplasia and inflammatory infiltrate as demonstrated in the histopathological screening, which are in accordance with earlier reports using the same animal model [21,31]. Defects in the colonic mucosal barrier functions are among the etiological factors that characterize IBD

Table 2 Effect of GS on histopathological changes of colonic tissues of rats with AA-induced UC

\begin{tabular}{|c|c|c|c|c|c|c|}
\hline & Ulceration & Hyperemia & Necrosis & Edema & Cellular Infiltrate & Goblet Cell Hyperplasia \\
\hline Cont & 0 & 0 & 0 & 0 & 0 & 0 \\
\hline AA & 3 & 3 & 4 & 3 & 4 & 2 \\
\hline$G S(50)+A A$ & 2 & 2 & 2 & 2 & 2 & 1 \\
\hline$G S(100)+A A$ & 1 & 1 & 1 & 1 & 2 & 1 \\
\hline$G S(200)+A A$ & 0 & 1 & 0 & 1 & 1 & 0 \\
\hline $\mathrm{MES}+\mathrm{AA}$ & 0 & 1 & 0 & 1 & 1 & 0 \\
\hline
\end{tabular}

0 : No abnormality detected;

1: Damage or active changes $<25 \%$;

2: Damage or active changes $<50 \%$;

3: Damage or active changes $<75 \%$;

4 : Damage or active changes $>75 \%$. 
[32]. In the current study, the protective colonic mucus content was markedly altered by AA, which is in agreement with the study by Popov et al. 2006 [24]. The mucus layer is well known to enhance the repair of the chemically damaged epithelium [33].

Several therapies have been used in the management of IBD. However, their adverse effects and toxicity represent major clinical problem [34]. Therefore, naturally occurring alternative options has been suggested along with the conventional therapies [35]. Our previous work demonstrated that GS leaves extract effectively protected against chemically induced gastric ulcers [33]. Results of the present study showed that the increased colon weight after AA administration was significantly reduced by the pretreatment of the animals with GS, indicating a decreased colon inflammation which was demonstrated by histopathological assessments. Pretreatments with GS inhibited colonic wall mucus depletion in the UC rat model, which could be attributed to its anti-inflammatory property, similar to our previous studies showing attenuation of the gastric mucosal damage-induced by absolute ethanol [33].

Both the reported forms of IBD are multi-factorial intestinal inflammatory disease, however, pro-inflammatory mediators is considered to play a crucial role in the pathogenesis of IBD [36]. They can modulate mucosal immune system, by the alteration of epithelial integrity and colon injury by infiltration of the neutrophils and macrophages [37]. Migration of granulocytes and other leukocytes to the inflamed mucosa and superficial ulcers results in overproduction of pro-inflammatory cytokines $[8,9]$. In both IBD forms, levels of pro-inflammatory cytokines, such as IL-1 $\beta$, TNF- $\alpha$, and IL-6, were found to be increased [38-40], which suggest that these inflammatory mediators are engaged in determining the severity of the disease. In the present study, pro-inflammatory cytokines including IL-1 $\beta$, TNF- $\alpha$, and IL- 6 were significantly elevated in colon tissues in AA administered group, suggesting a role of inflammation in the pathogenesis of the disease which is supported by the histopathological results showing epithelial cell necrosis, edema, and neutrophil infiltration in the tissue. Our findings are in agreement with earlier experimental and clinical data reported by others in a number of studies $[24,31,41,42]$. Next, we found increased colonic levels of $\mathrm{PGE}_{2}$ and $\mathrm{NO}$ in AA group of animals, which is in accordance with other investigations [43,44]. This increase in the levels of inflammatory molecules may be mediated through pro inflammatory cytokines. The anti-inflammatory properties of GS leaves extract were reported previously using various inflammatory animals models $[45,46]$. GS leaves extract was found to reduce the level of pro-inflammatory cytokines (IL-1 $\beta$, IL- 6 and TNF- $\alpha$ ) in AA colon tissue. The level of prostaglandins and $\mathrm{NO}$ is regulated by the cellular enzymes COX-2 and iNOS, respectively. These enzymes are known to be enhanced by inflammatory mediators during the burden of UC $[47,48]$. Therefore, we suggest the anti-inflammatory effect of $G S$ might be mediated through inhibiting the level $\mathrm{PGE}_{2}$ and $\mathrm{NO}$ in AA model of UC.

Oxidative stress is well known to play the major role in the pathophysiology of IBD $[49,50]$. Induction of UC in experimental animals causes oxidative injury due to imbalance between the levels of pro-oxidant and antioxidant systems [51]. UC is characterized by overproduction of reactive oxygen and nitrogen species leading to significant cellular adverse effects such as LPO and damage to tissue proteins and nucleic acids [10,52]. Furthermore, increased levels of free radicals were found in colonic tissue specimens of patients with UC $[53,54]$. Antioxidant enzymes such as SOD and CAT, and the non-enzymatic sulfhydryl groups play the major role in the organism defense against excess free radicals generated under disease conditions [55]. In the present investigation, concentrations of protein and non-protein sulfhydryl groups as well as activities of the antioxidant enzymes such as SOD and CAT were severely reduced in the colon following AA administration, which clearly indicates increased level of oxidative stress which may damage cells by lipid peroxidation of membranes and oxidation of cellular proteins. Indeed, increased levels of TBARS and free radicals found in the study may damage cells as observed by histopathological investigations.

Another damaging effect of oxidative stress have been noted in the present study, is in the alteration in the levels of nucleic acids and proteins in the colon of AA treated animals. These observations were also previously reported by others, which confirm the oxidative damages to cellular macromolecules thereby may weaken epithelial cellular integrity and delay colonic mucosal healing $[5,31]$. Thus, it is suggested that those substances that prevent free radicals production or potentiate the endogenous enzymatic or non-enzymatic antioxidant system can have beneficial effects in ulcerative colitis. In agreement with previous studies [56,57], pretreatment with GS increased antioxidant status and lowered LPO in AA model of UC which suggests its colonic protective effect by enhancing of nucleic acids and proteins levels. It is well known that GS has anti-diabetic properties with antioxidant activity [58]. Previously antioxidant and antiLPO effects of GS were reported in several animal models $[59,60]$ and also in an in vitro study by Rachh and colleagues, 2009 [61]. Several pharmacological studies have demonstrated that the antioxidant properties of GS are mainly through the major bioactive constituents in its leaves, which are a group of oleanane type triterpenoid saponins known as gymnemic acids [12,16], alkaloids, acidic glycosides and anthroquinones and their derivatives [17]. These constituents were also found in our preliminary phytochemical analysis from the GS leaves extract. 


\section{Conclusion}

Findings of the current investigation represent a clear evidence of the preventative ability of GS leaves extract against the damage in the experimentally induced UC by AA in Wistar rats. These protective effects could be attributed to the powerful anti-inflammatory and antioxidant properties present in the bioactive constituents of GS. The outcomes of present study may implicate in future clinical trials of the GS leaves extract or its bioactive constituents as natural, safe and effective treatments for patients with IBD.

\section{Competing interests}

The authors declare that they have no competing interests.

\section{Authors' contributions}

AMA, HMA and MYP have performed experimental designed, induction of colitis and animal treatment. HMA, MMA, MYP and SSA have carried out biochemical and statistical analysis as well as interpretation of the data. AMA participated with MSO in histopathological investigation and writing of the manuscript. SSA and MMA has revised and submitted the final manuscript. All authors read and approved the final manuscript.

\section{Acknowledgement}

The authors extend their appreciation to the Deanship of Scientific Research at King Saud University for funding the work through the research group project No RGP-VPP-263.

\section{Author details}

1 Department of Pharmacology and Toxicology, College of Pharmacy, King Saud University, P.O. Box 2457, Riyadh 11451, Saudi Arabia. ${ }^{2}$ Department of Biomedical Dental Sciences, College of Dentistry, Dammam University, Dammam 31441, Saudi Arabia. ${ }^{3}$ Department of Biochemistry, College of Science, King Saud University, Riyadh 11415, Saudi Arabia.

Received: 13 November 2013 Accepted: 6 February 2014 Published: 10 February 2014

\section{References}

1. Sood A, Midha V, Sood N, Bhatia AS, Avasthi G: Incidence and prevalence of ulcerative colitis in Punjab. North India. Gut 2003, 52(11):1587-1590.

2. Olden KW: Diagnosis of irritable bowel syndrome. Gastroenterology 2002, 122(6):1701-1714

3. Nieto N, Torres Ml, Rios A, Gil A: Dietary polyunsaturated fatty acids improve histological and biochemical alterations in rats with experimental ulcerative colitis. J Nutr 2002, 132(1):11-19.

4. Slamon ND, Pentreath W: Antioxidant defense against antidepressants in C6 and 1321 N1 cells. Chem Biol Interact 2000, 127(3):181-199.

5. Cetinkaya A, Bulbuloglu E, Kantarceken B, Ciralik H, Kurutas EB, Buyukbese MA, Gumusalan Y: Effects of L-carnitine on oxidant/antioxidant status in acetic acid-induced colitis. Dig Dis Sci 2006, 51(3):488-494.

6. Cetinkaya A, Bulbuloglu E, Kurutas EB, Ciralik H, Kantarceken B, Buyukbese MA: Beneficial effects of $\mathrm{N}$-acetylcysteine on acetic acid-induced colitis in rats. Tohoku J Exp Med 2005, 206(2):131-139.

7. Reiff C, Kelly D: Inflammatory bowel disease, gut bacteria and probiotic therapy. Int J Med Microbiol 2010, 300(1):25-33.

8. Pavlick KP, Laroux FS, Fuseler J, Wolf RE, Gray L, Hoffman J, Grisham MB: Role of reactive metabolites of oxygen and nitrogen in inflammatory bowel disease. Free Radic Biol Med 2002, 33(3):311-322

9. Grisham MB: Oxidants and free radicals in inflammatory bowel disease. Lancet 1994, 344(8926):859-861.

10. Tuzun A, Erdil A, Inal V, Aydin A, Bagci S, Yesilova Z, Sayal A, Karaeren N, Dagalp K: Oxidative stress and antioxidant capacity in patients with inflammatory bowel disease. Clin Biochem 2002, 35(7):569-572.

11. Chang JC, Cohen RD: Medical management of severe ulcerative colitis. Gastroenterol Clin North Am 2004, 33(2):235-250. viii.

12. Kanetkar P, Singhal R, Kamat M: Gymnema sylvestre: A Memoir. J Clin Biochem Nutr 2007, 41(2):77-81.
13. Daisy P, Eliza J, Mohamed Farook KA: A novel dihydroxy gymnemic triacetate isolated from Gymnema sylvestre possessing normoglycemic and hypolipidemic activity on STZ-induced diabetic rats. J Ethnopharmaco/ 2009, 126(2):339-344.

14. Ramkumar KM, Ponmanickam P, Velayuthaprabhu S, Archunan G, Rajaguru P: Protective effect of Gymnema montanum against renal damage in experimental diabetic rats. Food Chem Toxicol 2009, 47(10):2516-2521.

15. Grover JK, Yadav S, Vats V: Medicinal plants of India with anti-diabetic potential. J Ethnopharmacol 2002, 81(1):81-100.

16. Ye WC, Zhang QW, Liu X, Che CT, Zhao SX: Oleanane saponins from Gymnema sylvestre. Phytochemistry 2000, 53(8):893-899.

17. Surveswaran S, Cai YZ, Xing J, Corke H, Sun M: Antioxidant properties and principal phenolic phytochemicals of Indian medicinal plants from Asclepiadoideae and Periplocoideae. Nat Prod Res 2010, 24(3):206-221.

18. Trease EGaE, W.E: Saponins and cardioactive drugs, Textbook of Pharmacognosy. London: Bailiere Tindal; 1978.

19. Al-Rejaie SS, Abuohashish HM, Al-Enazi MM, Al-Assaf AH, Parmar MY, Ahmed MM: Protective effect of naringenin on acetic acid-induced ulcerative colitis in rats. World j gastroenterol WJG 2013, 19(34):5633-5644.

20. Koch TR, Yuan LX, Stryker SJ, Ratliff P, Telford GL, Opara EC: Total antioxidant capacity of colon in patients with chronic ulcerative colitis. Dig dis sci 2000, 45(9):1814-1819.

21. Harputluoglu MM, Demirel U, Yucel N, Karadag N, Temel I, Firat S, Ara C, Aladag M, Karincaoglu M, Hilmioglu F: The effects of Gingko biloba extract on acetic acid-induced colitis in rats. Turk j gastroenterol off j Turk Soc Gastroenterol 2006, 17(3):177-182.

22. Kannan N, Guruvayoorappan C: Protective effect of Bauhinia tomentosa on acetic acid induced ulcerative colitis by regulating antioxidant and inflammatory mediators. Int immunopharmacol 2013, 16(1):57-66.

23. Mousavizadeh K, Rahimian R, Fakhfouri G, Aslani FS, Ghafourifar P: Anti-inflammatory effects of 5-HT receptor antagonist, tropisetron on experimental colitis in rats. Eur J Clin Invest 2009, 39(5):375-383.

24. Popov SV, Markov PA, Nikitina IR, Petrishev S, Smirnov V, Ovodov YS: Preventive effect of a pectic polysaccharide of the common cranberry Vaccinium oxycoccos L. on acetic acid-induced colitis in mice. World J Gastroenterol 2006, 12(41):6646-6651.

25. Sedlak J, Lindsay RH: Estimation of total, protein-bound, and nonprotein sulfhydryl groups in tissue with Ellman's reagent. Anal Biochem 1968, 25(1):192-205.

26. Kono Y: Generation of superoxide radical during autoxidation of hydroxylamine and an assay for superoxide dismutase. Arch Biochem Biophys 1978, 186(1):189-195.

27. Aebi H: Catalase. In Methods in enzymatic analysis. 2nd edition. Edited by Bergmeyer. New York: Verlag Chemie-Academic Press; 1974:674-684.

28. Bregman A: Laboratory Investigation and Cell Biology. New York: John Wiley and Sons; 1983

29. Lowry OH, Rosebrough NJ, Farr AL, Randall RJ: Protein measurement with the Folin phenol reagent. J Biol Chem 1951, 193(1):265-275.

30. Hartmann RM, Morgan Martins MI, Tieppo J, Fillmann HS, Marroni NP: Effect of Boswellia serrata on antioxidant status in an experimental model of colitis rats induced by acetic acid. Dig Dis Sci 2012, 57(8):2038-2044.

31. El-Abhar HS, Hammad LN, Gawad HS: Modulating effect of ginger extract on rats with ulcerative colitis. J Ethnopharmacol 2008, 118(3):367-372.

32. Duerr $\mathrm{RH}$ : Update on the genetics of inflammatory bowel disease. J Clin Gastroenterol 2003, 37(5):358-367.

33. Al-Rejaie SS, Abuohashish HM, Ahmed MM, Aleisa AM, Alkhamees O: Possible biochemical effects following inhibition of ethanol-induced gastric mucosa damage by Gymnema sylvestre in male Wistar albino rats. Pharm Biol 2012, 50(12):1542-1550.

34. Sands BE: Therapy of inflammatory bowel disease. Gastroenterology 2000 118(2 Suppl 1):S68-82.

35. Langmead L, Dawson C, Hawkins C, Banna N, Loo S, Rampton DS: Antioxidant effects of herbal therapies used by patients with inflammatory bowel disease: an in vitro study. Aliment Pharmacol Ther 2002, 16(2):197-205.

36. Button LA, Roberts SE, Goldacre MJ, Akbari A, Rodgers SE, Williams JG: Hospitalized prevalence and 5-year mortality for IBD: record linkage study. World J Gastroenterol 2010, 16(4):431-438.

37. Grisham MB, Yamada T: Neutrophils, nitrogen oxides, and inflammatory bowel disease. Ann N Y Acad Sci 1992, 664:103-115. 
38. Sartor RB: Cytokines in intestinal inflammation: pathophysiological and clinical considerations. Gastroenterology 1994, 106(2):533-539.

39. Elson CO, Sartor RB, Tennyson GS, Riddell RH: Experimental models of inflammatory bowel disease. Gastroenterology 1995, 109(4):1344-1367.

40. Bertevello PL, Logullo AF, Nonogaki S, Campos FM, Chiferi V, Alves CC, Torrinhas RS, Gama-Rodrigues JJ, Waitzberg DL: Immunohistochemical assessment of mucosal cytokine profile in acetic acid experimental colitis. Clinics (Sao Paulo) 2005, 60(4):277-286.

41. Stucchi A, Reed K, O'Brien M, Cerda S, Andrews C, Gower A, Bushell K, Amar S, Leeman S, Becker J: A new transcription factor that regulates TNF-alpha gene expression, LITAF, is increased in intestinal tissues from patients with CD and UC. Inflamm Bowel Dis 2006, 12(7):581-587.

42. Tahan G, Aytac E, Aytekin H, Gunduz F, Dogusoy G, Aydin S, Tahan V, Uzun $\mathrm{H}$ : Vitamin $\mathrm{E}$ has a dual effect of anti-inflammatory and antioxidant activities in acetic acid-induced ulcerative colitis in rats. Can J Surg 2011, 54(5):333-338.

43. Otani T, Yamaguchi K, Scherl E, Du B, Tai HH, Greifer M, Petrovic L, Daikoku T, Dey SK, Subbaramaiah K, et al: Levels of NAD(+)-dependent 15-hydroxyprostaglandin dehydrogenase are reduced in inflammatory bowel disease: evidence for involvement of TNF-alpha. Am J Physiol Gastrointest Liver Physiol 2006, 290(2):G361-368.

44. Park MY, Ji GE, Sung MK: Dietary kaempferol suppresses inflammation of dextran sulfate sodium-induced colitis in mice. Dig Dis Sci 2012, 57(2):355-363.

45. Diwan PV, Margaret I, Ramakrishna S: Influence of Gymnema sylvestre on inflammation. InflammoPharmacology 1995, 3(3):271-277.

46. Jitender KM, Manvi F, Alagawadi K, Noolvi M: Evaluation of anti-inflammatory activity of Gymnema sylvestre leaves extract in rats. IJGP 2008, 2(2):114-115.

47. Hamalainen M, Nieminen R, Vuorela P, Heinonen M, Moilanen E: Anti-inflammatory effects of flavonoids: genistein, kaempferol, quercetin, and daidzein inhibit STAT-1 and NF-kappaB activations, whereas flavone, isorhamnetin, naringenin, and pelargonidin inhibit only NF-kappaB activation along with their inhibitory effect on iNOS expression and NO production in activated macrophages. Mediators Inflamm 2007, 2007:45673

48. Raso GM, Meli R, Di Carlo G, Pacilio M, Di Carlo R: Inhibition of inducible nitric oxide synthase and cyclooxygenase-2 expression by flavonoids in macrophage J774A.1. Life Sci 2001, 68(8):921-931.

49. Patel MA, Patel PK, Patel MB: Effects of ethanol extract of Ficus bengalensis (bark) on inflammatory bowel disease. Indian J Pharmacol 2010, 42(4):214-218.

50. Narushima S, Spitz DR, Oberley LW, Toyokuni S, Miyata T, Gunnett CA, Buettner GR, Zhang J, Ismail H, Lynch RG, et al: Evidence for oxidative stress in NSAID-induced colitis in IL10-/- mice. Free Radic Biol Med 2003, 34(9):1153-1166.

51. Droge W: Free radicals in the physiological control of cell function. Physiol Rev 2002, 82(1):47-95.

52. Pravda J: Radical induction theory of ulcerative colitis. World $J$ Gastroenterol 2005, 11(16):2371-2384.

53. Bitiren M, Karakilcik AZ, Zerin M, Ozardali I, Selek S, Nazligul Y, Ozgonul A, Musa D, Uzunkoy A: Protective effects of selenium and vitamin E combination on experimental colitis in blood plasma and colon of rats. Biol Trace Elem Res 2010, 136(1):87-95.

54. Ademoglu E, Erbil Y, Tam B, Barbaros U, Ilhan E, Olgac V, Mutlu-Turkoglu U: Do vitamin $E$ and selenium have beneficial effects on trinitrobenzenesulfonic acid-induced experimental colitis. Dig Dis Sci 2004, 49(1):102-108.

55. Yu BP: Cellular defenses against damage from reactive oxygen species. Physiol Rev 1994, 74(1):139-162

56. Cai DJ, Zhao Y, Glasier J, Cullen D, Barnes S, Turner CH, Wastney M, Weaver CM: Comparative effect of soy protein, soy isoflavones, and 17beta-estradiol on bone metabolism in adult ovariectomized rats. J Bone Miner Res 2005, 20(5):828-839.

57. Preuss HG, Jarrell ST, Scheckenbach R, Lieberman S, Anderson RA: Comparative effects of chromium, vanadium and gymnema sylvestre on sugar-induced blood pressure elevations in SHR. J Am Coll Nutr 1998, 17(2):116-123

58. Kang MH, Lee MS, Choi MK, Min KS, Shibamoto T: Hypoglycemic activity of Gymnema sylvestre extracts on oxidative stress and antioxidant status in diabetic rats. J Agric Food Chem 2012, 60(10):2517-2524.
59. Kumar V, Bhandari U, Tripathi CD, Khanna G: Evaluation of antiobesity and cardioprotective effect of Gymnema sylvestre extract in murine model. Indian J Pharmacol 2012, 44(5):607-613.

60. Sharma K, Singh U, Vats S, Priyadarsini K, Bhatia A, Kamal R: Evaluation of evidenced-based radioprotective efficacy of Gymnema sylvestre leaves in mice brain. J Environ Pathol Toxicol Oncol 2009, 28(4):311-323.

61. Rachh PR, Patel SR, Hirpara HV, Rupareliya MT, Rachh MR, Bhargava AS, Patel NM, Modi DC: In vitro evaluation of antioxidant activity of Gymnema sylvestre R. BR leaf extract Rom J Biol 2009, 54(2):141-148.

\section{doi:10.1186/1472-6882-14-49}

Cite this article as: Aleisa et al: Pretreatment of Gymnema sylvestre revealed the protection against acetic acid-induced ulcerative colitis in rats. BMC Complementary and Alternative Medicine 2014 14:49.

\section{Submit your next manuscript to BioMed Central and take full advantage of:}

- Convenient online submission

- Thorough peer review

- No space constraints or color figure charges

- Immediate publication on acceptance

- Inclusion in PubMed, CAS, Scopus and Google Scholar

- Research which is freely available for redistribution 